\title{
Association of insufficient practice of physical activity with demographic, anthropometric and biochemical factors in hypertensive patients
}

\section{Fatores associados à atividade física em pacientes com hipertensão tratados e monitorados pelo Hiperdia}

\author{
Nayra Anielly Cabral Cantanhede ${ }^{1}$ (D), Valdinar Sousa Ribeiro ${ }^{2}$ (D), \\ Ana Karina Teixeira da Cunha França ${ }^{3}$ (D), Elane Viana Hortegal ${ }^{3}$ (D), \\ Alcione Miranda dos Santos ${ }^{4}$ (D), Wellington Roberto Gomes de Carvalho ${ }^{5}$ (D), \\ Isabelle Christine Vieira da Silva Martins ${ }^{6}$ (D) , Luciana Pereira Pinto Dias ${ }^{7}$ (D), \\ Natalino Salgado Filho ${ }^{8}$ (D) \\ 'Departamento de Nutrição, Universidade Federal do Maranhão (UFMA) - São Luís (MA), Brasil. \\ ${ }^{2}$ Departamento de Medicina III, Universidade Federal do Maranhão (UFMA) - São Luís (MA), Brasil. \\ ${ }^{3}$ Departamento de Nutrição, Universidade Federal do Maranhão (UFMA) - São Luís (MA), Brasil. \\ ${ }^{4}$ Departamento de Saúde Pública, Universidade Federal do Maranhão (UFMA) - São Luís (MA), Brasil. \\ ${ }^{5}$ Departamento de Saúde Pública, Universidade Federal do Triângulo Mineiro (UFMA) - Uberaba (MG), Brasil. \\ ${ }^{6}$ Programa de Graduação em Neurociências e Biologia Celular, Universidade Federal do Pará (UFPA) - Belém (PA), Brasil. \\ ?Universidade Ceuma (UniCEUMA) - São Luís (MA), Brasil. \\ ${ }^{8}$ Departamento de Medicina I, Universidade Federal do Maranhão (UFMA) - São Luís (MA), Brasil.
}

How to cite Cantanhede NAC, Ribeiro VS, França AKTC, Hortegal EV, Santos AM, Carvalho WRG, et al. Association of insufficient practice of physical activity with demographic, anthropometric and biochemical factors in hypertensive patients. Cad Saúde Colet, 2021;29(4):474-484. https://doi.org/10.1590/1414-462X202129040161

\section{Resumo}

Introdução: Considerando-se a magnitude da hipertensão arterial sistêmica e suas complicações, assim como a importância da atividade física regular na sua prevenção e/ou tratamento, é necessário identificar os fatores associados à prática de atividade física insuficiente. Objetivo: Analisar os fatores associados à atividade física insuficiente em hipertensos atendidos na atenção primária à saúde. Método: Estudo transversal realizado com amostra aleatória de 305 hipertensos em três unidades de saúde de São Luís (MA). Foi realizada análise bivariada, com estimativas de razões de prevalência, intervalos de confiança e análise multivariada por regressão de Poisson. Resultados: A atividade física insuficiente foi observada em 38,7\% da amostra. Atividade física insuficiente foi associada a menos de 8 anos de educação formal (razão de prevalência - RP = 1,58; intervalo de confiança de $95 \%$ - IC = 1,04-2,39), colesterol total $\geq 200 \mathrm{mg} / \mathrm{dL}(\mathrm{RP}=0,78$; IC 95\% = 0,58 -1,04), lipoproteína de baixa densidade colesterol-LDLC $\geq 100 \mathrm{mg} / \mathrm{dL}(\mathrm{RP}=0,79 ; \mathrm{IC} 95 \%=0,53-0,95)$ e lipoproteína de alta densidade colesterol-HDLc $<40 \mathrm{mg} / \mathrm{dL}$ entre homens e $<50 \mathrm{mg} / \mathrm{dL}$ entre mulheres $(\mathrm{RP}=1,21$; IC $95 \%=0,90-1,64)$. A escolaridade $<8$ anos ( $R P=1,50 ;$ IC $95 \%=0,99-2,29$ ) e LDLC $\geq 100 \mathrm{mg} / \mathrm{dL}$ $(\mathrm{RP}=0,72 ; \mathrm{IC} 95 \%=0,54-0,96)$ também estiveram associados na regressão multivariada. Conclusão: Observou-se alta prevalência de atividade física insuficiente e sua associação com baixa escolaridade e LDLc alterado em hipertensos.

Palavras-Chave: atividade motora; hipertensão; atenção primária à saúde.

\footnotetext{
Abstract

Trabalho realizado na Universidade Federal do Maranhão (UFMA) - São Luís (MA), Brasil.

*Correspondência: Nayra Anielly Cabral Cantanhede. E-mail: n_anielly@yahoo.com.br

Conflict of interests: nothing to declare.

Recebido em: Ago. 06, 2017. Aprovado em: Abr. 05, 2020
}

Background: Considering the magnitude of systemic hypertension $(\mathrm{SH})$ and its complications, as well as the importance of regular physical activity in its prevention and/or treatment, there is a necessity to identify the factors associated with insufficient practice of physical activity. Objective: To analyze factors associated with insufficient physical activity in hypertensive patients treated at Primary Health Care
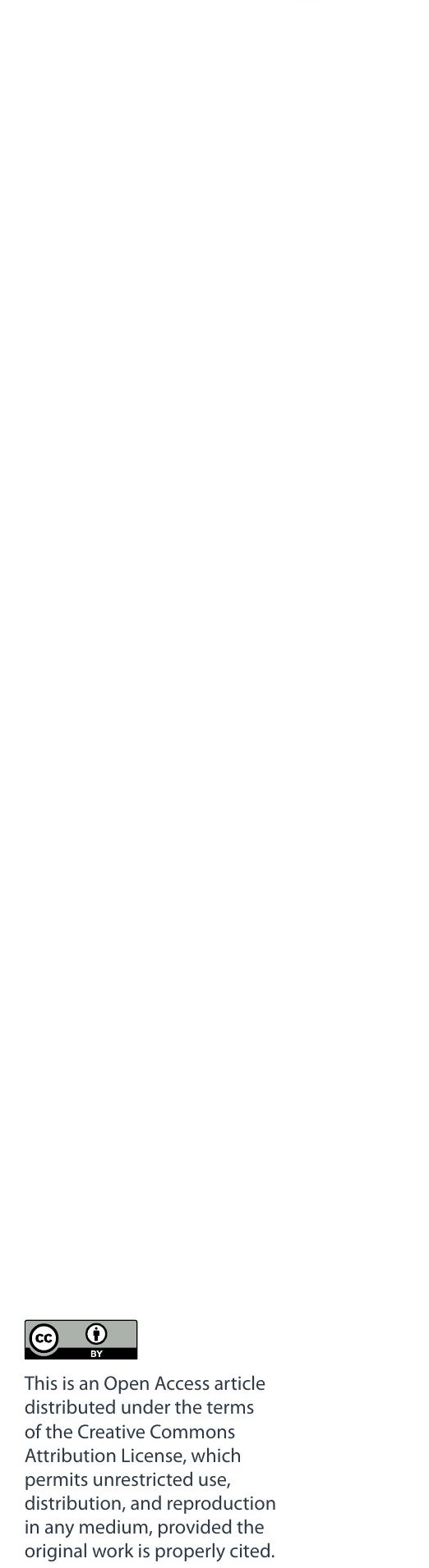

This is an Open Access article distributed under the terms of the Creative Commons Attribution License, which distribution, and reproduction original work is properly cited. 
(PHC). Method: This cross-sectional study was performed with a random sample of 305 hypertensive patients in three PHC units in São Luis, state of Maranhão, Brazil. A bivariate analysis was performed with estimates of prevalence ratios and confidence intervals, and multivariate analysis using Poisson regression. Results: Insufficient physical activity was observed in $38.7 \%$ of the sample. Insufficient physical activity was associated with having $<8$ years of formal education (prevalence ratio-PR $=1.58$; $95 \%$ confidence interval- $\mathrm{Cl}=1.04-2.39)$, total cholesterol $\geq 200 \mathrm{mg} / \mathrm{dL}(\mathrm{PR}=0.78 ; 95 \% \mathrm{Cl}=0.58-1.04)$, low-density lipoprotein cholesterol-LDL $\geq 100 \mathrm{mg} / \mathrm{dL}$ ( $\mathrm{PR}=0.79 ; 95 \% \mathrm{Cl}=0.53-0.95$ ), and high-density lipoprotein cholesterol-HDL $<40 \mathrm{mg} / \mathrm{dL}$ among men and $<50 \mathrm{mg} / \mathrm{dL}$ among women $(\mathrm{PR}=1.21 ; 95 \%$ $\mathrm{Cl}=0.90-1.64)$. Length of education $<8$ years $(\mathrm{PR}=1.50 ; 95 \% \mathrm{Cl}=0.99-2.29)$ and $\mathrm{LDL} \geq 100 \mathrm{mg} / \mathrm{dL}$ $(\mathrm{PR}=0.72 ; 95 \% \mathrm{Cl}=0.54-0.96)$ were also associated in the multivariate regression. Conclusion: High prevalence of insufficient physical activity and its association with low education level and altered LDL serum levels were observed in hypertensive patients.

Keywords: motor activity; hypertension; primary health care.

\section{INTRODUCTION}

Promotion of physical activity is a priority of the Global Strategy on Diet, Physical Activity and Health of the World Health Organization (WHO). The objectives of this strategy are to develop, strengthen, and implement global, national and regional policies for the adoption of healthy habits by the population?

However, physical inactivity is the fourth leading cause of death worldwide. The factors associated with physical inactivity include older age range, gender, partner presence, higher income, education, low consumption of fruits, negative quality of life (QoL) perception, and hypertension ${ }^{2,3,4}$.

Physical inactivity is associated with systemic hypertension $(\mathrm{SH})^{4}$ and dyslipidemia 5 . Physical activity stimulates the production of vasodilators and improves the endothelial function, leading to a more favorable lipid profile. It is also an important tool in the treatment of $\mathrm{SH}$ because the regular practice of physical exercise leads to significant cardiovascular adaptations, including the reduction of blood pressure (BP) levels in hypertensive individuals ${ }^{6}$. Physical exercise helps to control $\mathrm{SH}$ and may even lead to the discontinuation of medication use, reduction in the dose or number of antihypertensive medications, increased functional capacity, and improved QoL and disease prognosis ${ }^{6}$. The high rates of physical inactivity and harmful effects arising from this habit have become a global concern'. Thus, various instruments aimed at measuring the level of physical activity have been developed. Among them, the International Physical Activity Questionnaire (IPAQ) has been tested and validated to quantify the levels of physical activity at different stages of life in 12 countries, including Brazil. This instrument is easy to use, non-invasive, of low cost, targets various population groups, and presents a low risk to the individual?.

Considering the magnitude of $\mathrm{SH}$ and its complications, as well as the importance of regular physical activity in its prevention and/or treatment, the present study aimed to determine the factors associated with insufficient physical activity in hypertensive patients treated at Primary Health Care (PHC) units in São Luis, the capital of the state of Maranhão, in Brazil.

\section{METHOD}

This is a cross-sectional study conducted with hypertensive patients treated and followed up by the Program for Registering and Monitoring of Hypertensive and Diabetic Patients (HiperDia). Data collection was carried out from January 2010 to December 2012.

The study included hypertensive patients aged $\geq 20$ years. The exclusion criteria were pregnant women and patients with any other chronic consumptive disease (cancer and acquired immune deficiency syndrome) or who were undergoing renal replacement therapy.

The selection process began through the medical records of the PHC units, and simple random sampling with replacement was conducted. Subsequently, a list with the names of 
the hypertensive patients registered in the HiperDia program of the Family Health Strategy (FHS) surveyed units was obtained, and simple random sampling without replacement was conducted.

The sample size was calculated using the total number of hypertensive patients registered at HiperDia program of the surveyed PHC units (850), prevalence of hypertension of $26.7 \%{ }^{8}$, a $4 \%$ margin of error, and a $95 \%$ confidence level $(\mathrm{Cl})$. Thus, the sample size was estimated at 303 patients. Because losses were predicted, the sample size was increased by $10 \%$, to a total of 333 patients. The sample consisted of 305 hypertensive patients after the loss of 10 patients who did not agree to participate in the study and 18 due to insufficient data.

Data collection was conducted using a structured questionnaire administered by a team composed of Nutrition, Medicine and Nursing students under the supervision of Nutrition and Medicine professors.

The dependent variable was physical activity, which was assessed using the short version of the IPAQ ${ }^{7}$, in which individuals with $<150$ min of physical activity per week were considered insufficiently active (irregularly active and/or inactive), and those who practiced $\geq 150$ min of physical activity per week were considered active (active and/or very active). This classification was chosen based on for the practice of physical activity in adults and older patients 9 .

The independent variables were sex, age, skin color, education level, socioeconomic status, alcohol consumption, smoking habit, body mass index (BMI), waist circumference (WC), waistto-hip ratio (WHR), and the levels of fasting glucose, triglycerides, total cholesterol, low-density lipoprotein (LDL) cholesterol, and high-density lipoprotein (HDL) cholesterol.

Socioeconomic, demographic, lifestyle, anthropometric, clinical and laboratory data were evaluated. The variable age was categorized as $\geq 20$ and $<40$ years, $\geq 40$ and $<60$ years, and $\geq 60$ years. The socioeconomic classification criterion followed that established by the Brazilian Association of Research Companies ${ }^{10}$, which estimates the purchasing power of individuals and families living in urban centers.

Education level was assessed in number of years of formal education and categorized into $\leq 8$ and $>8$ years of schooling. Skin color was self-reported ${ }^{10}$, and classified as white and nonwhite. Smokers (smoking habit) and/or drinkers (alcohol consumption) were classified as those who, during the interview, reported the use of cigarettes or alcohol, regardless of frequency.

The anthropometric assessment was performed with measurements of weight (in kilograms) using a portable digital scale (Plena ${ }^{\circ}$ ), height (in meters) using a stadiometer (Alturexata ${ }^{\circ}$ ), and WC by using a non-elastic measuring tape. The WC (in centimeters) was obtained at the midpoint between the last rib and the iliac crest at expiration, and the cutoff points were $88 \mathrm{~cm}$ for women and $102 \mathrm{~cm}$ for men ${ }^{11}$. The WHR was calculated by dividing the WC by WC, and the cutoff points were 0.85 for women and 1.0 for men ${ }^{11}$. The weight-for-height adequacy was determined by the $\mathrm{BMI}$, which was obtained from the ratio of the body weight to the squared height, and was categorized as overweight $\left(\mathrm{BMI} \geq 30.0 \mathrm{~kg} / \mathrm{m}^{2}\right)$ and absence of excess weight $\left(\mathrm{BMI}<25.0 \mathrm{~kg} / \mathrm{m}^{2}\right)$ according to the $\mathrm{WHO}^{12}$; for older individuals, the categories were overweight $\left(\mathrm{BMI}>22 \mathrm{~kg} / \mathrm{m}^{2}\right)$ and absence of excess weight $\left(\mathrm{BMl}<22 \mathrm{~kg} / \mathrm{m}^{2}\right)^{13}$.

For the clinical laboratory assessment, the levels of serum total cholesterol (TC), HDL cholesterol ( $<50 \mathrm{mg} / \mathrm{dl}$ for women and $<40 \mathrm{mg} / \mathrm{dl}$ for men), LDL cholesterol $(\geq 100 \mathrm{mg} / \mathrm{dl})$, triglycerides (TGs) $(\geq 150 \mathrm{mg} / \mathrm{dl})$, and fasting plasma glucose (FPG) $(\geq 100 \mathrm{mg} / \mathrm{dl})$ were used ${ }^{14}$. The HDL cholesterol, LDL cholesterol, total cholesterol, triglycerides and fasting plasma glucose levels were analyzed by the Inlab Laboratory. The patients' blood pressure (BP) levels were indirectly measured using a digital automatic sphygmomanometer (Omron ${ }^{\circ}$ Model 705), with cuffs of appropriate sizes, following the recommendations of the $7^{\text {th }}$ Brazilian Guidelines of Arterial Hypertension ${ }^{15}$. BP was considered normal when the mean systolic BP was $<140 \mathrm{mmHg}$ and the mean diastolic BP was $<90 \mathrm{mmHg}$.

All patients were evaluated by physicians to receive diagnosis or not of diabetes. After that, the variable glycemia was categorized as non-diabetic with FPG $<100 \mathrm{mg} / \mathrm{dL}$; a second category, diabetic and non-diabetic, with FPG $\geq 100 \mathrm{mg} / \mathrm{dL}$, was also used. Regarding changes in FPG, the parameters established by the American Diabetes Association (ADA, 2010) ${ }^{16}$ were used, namely, normal FPG - serum values $\leq 100 \mathrm{mg} / \mathrm{dL}$, altered FPG - serum levels $\geq 100 \mathrm{mg} / \mathrm{dL}$, or 
under hypoglycemic medicine therapy. LDL and HDL cholesterol levels were considered altered according to the values recommended by the National Cholesterol Education Program (NCEP) expert panel on detection, evaluation and treatment of high blood cholesterol in adults (NCEPATPIII, 2002) ${ }^{17}: \mathrm{HDL}<40 \mathrm{mg} / \mathrm{dL}$ for men and $<50 \mathrm{mg} / \mathrm{dL}$ for women; $\mathrm{LDL} \geq 100 \mathrm{mg} / \mathrm{dL}$. Regarding changes in FPG, the parameters established by the American Diabetes Association ${ }^{16}$ were used, namely, normal glycaemia - serum values $\leq 100 \mathrm{mg} / \mathrm{dL}$, altered glycaemia - serum levels $\geq 100 \mathrm{mg} / \mathrm{dL}$, or under hypoglycemic medicine therapy.

Normality of the quantitative variables was analyzed by the Shapiro-Wilks test. The data were presented as the mean and standard deviation (mean \pm SD) for the quantitative variables, and as frequency and percentage for the qualitative variables.

In the multivariate analysis (Poisson regression), the dependent variable physical activity was allocated to the bivariate analysis (color, smoking habit, BMI, FPG, total cholesterol, and $\mathrm{HDL}$ cholesterol) - thus, those that presented $p>0.05$ until they presented statistical significance $p<0.05$. The data were analyzed using the STATA 10.0 statistical software.

Patients who agreed to participate in the study signed An Informed Consent Form (ICF). The present study was approved by the Ethics Research Committee of the Presidente Dutra University Hospital under protocol no. 312/09.

\section{RESULTS}

A total of 305 patients with a mean age of $60.7 \pm 11.8$ years were evaluated, with predominance of older $(55.4 \%)$, female $(75.1 \%)$, with a partner $(65.6 \%)$ and non-white $(85.9 \%)$ patients. Most of the hypertensive patients belonged to socioeconomic class $C(51.8 \%)$ and had fewer than 8 years of formal education (76.7\%). Regarding lifestyle, $38.7 \%$ of the patients were considered insufficiently active, $69.5 \%$ did not smoke, and $64.3 \%$ did not consume alcohol (Table 1).

The mean time since $\mathrm{SH}$ diagnosis was $10.4 \pm 9.3$ years, and the prevalence of uncontrolled blood pressure ( $\geq 140 \times 90 \mathrm{mmHg}$ ) was $61.0 \%$. There was high prevalence of overweight (BMI $\geq 25.0 \mathrm{~kg} / \mathrm{m}^{2}$ for patients aged $<60$ years and $\geq 27.0 \mathrm{~kg} / \mathrm{m}^{2}$ for patients aged $\geq 60$ years) $(59.0 \%$ ), as well as of altered WC (56.5\%) and WHR (76.2\%). Similarly, most patients had serum levels above those recommended for total cholesterol (54.5\%) and LDL cholesterol (76.4\%), while $66.7 \%$ had HDL cholesterol levels below the recommended levels. Prevalence of diabetic and nondiabetic patients with FPG $\geq 100 \mathrm{mg} / \mathrm{dL}$ was $50.7 \%$, and $40.7 \%$ presented hypertriglyceridemia (TG $\geq 150 \mathrm{mg} / \mathrm{dL}$ ) (Table 2).

The univariate analysis showed that insufficient physical activity was associated with having fewer than 8 years of formal education (prevalence ratio $(\mathrm{PR})=1.58 ; 95 \%$ confidence interval $(\mathrm{Cl})=1.04-2.39$ ), total cholesterol $\geq 200 \mathrm{mg} / \mathrm{dL}(\mathrm{PR}=0.78 ; 95 \% \mathrm{Cl}=0.58-1.04)$, LDL cholesterol $\geq 100 \mathrm{mg} / \mathrm{dL}$ ( $\mathrm{PR}=0.71 ; 95 \% \mathrm{Cl}=0.53-0.95)$, and $\mathrm{HDL}$ cholesterol $<40 \mathrm{mg} / \mathrm{dL}$ for men and $<50 \mathrm{mg} / \mathrm{dL}$ for women ( $\mathrm{PR}=1.21 ; 95 \% \mathrm{Cl}=0.90-1.64$ ) (Tables 3 and 4).

Finally, after the adjusted analysis, only fewer than 8 years of formal education ( $P R=1.50$; $95 \% \mathrm{Cl}=0.99-2.29)$ and $\mathrm{LDL}$ cholesterol $\geq 100 \mathrm{mg} / \mathrm{dL}(\mathrm{PR}=0.72 ; 95 \% \mathrm{Cl}=0.54-0.96)$ were associated with insufficient physical activity (Table 5).

\section{DISCUSSION}

The prevalence of insufficiently active individuals among the hypertensive patients followed up by the HiperDia program was significant. Most of the hypertensive patients in this study were female, older, non-white individuals with fewer than 8 years of formal education who belonged to socioeconomic class $C$, followed by the $D$ and $E$ classes. They also had excess body weight, accumulation of fat in the abdominal area, and abnormal serum levels of LDL cholesterol and FPG. After the adjusted analysis, having fewer than 8 years of formal education and LDL cholesterol $\geq 100 \mathrm{mg} / \mathrm{dL}$ were associated with insufficient physical activity.

Regarding socioeconomic characteristics, a higher frequency of hypertensive patients aged $\geq 60$ years has been commonly described in the literature ${ }^{18,19}$. This finding is attributed, in part, to the aging of the population ${ }^{19}$ and to the collinearity of $\mathrm{SH}$ with aging ${ }^{20}$. 
Table 1. Sociodemographic characteristics and lifestyle of hypertensive patients followed up by the HiperDia program, state of São Luís, Maranhão, Brazil, 2010-2012

\begin{tabular}{|c|c|c|}
\hline Variables & $\mathbf{n}$ & $\%$ \\
\hline \multicolumn{3}{|l|}{ Sex } \\
\hline Male & 76 & 24.9 \\
\hline Female & 229 & 75.1 \\
\hline \multicolumn{3}{|l|}{ Age } \\
\hline 20-39 years & 17 & 5.6 \\
\hline $40-59$ years & 119 & 39.0 \\
\hline$\geq 60$ years & 169 & 55.4 \\
\hline \multicolumn{3}{|l|}{ Socioeconomic status* } \\
\hline Classes $A$ and $B$ & 42 & 13.8 \\
\hline Classes $\mathrm{C} 1$ and $\mathrm{C} 2$ & 158 & 51.8 \\
\hline Classes $\mathrm{D}$ and $\mathrm{E}$ & 105 & 34.4 \\
\hline \multicolumn{3}{|l|}{ Marital status } \\
\hline With a partner & 200 & 65.6 \\
\hline Without a partner & 105 & 34.4 \\
\hline \multicolumn{3}{|l|}{ Skin color } \\
\hline White & 43 & 14.1 \\
\hline Non-white & 262 & 85.9 \\
\hline \multicolumn{3}{|l|}{ Years of schooling } \\
\hline$\geq 8$ & 71 & 23.3 \\
\hline$<8$ & 234 & 76.7 \\
\hline \multicolumn{3}{|l|}{ Smoking habit } \\
\hline No or former & 212 & 69.5 \\
\hline Yes & 93 & 30.5 \\
\hline \multicolumn{3}{|l|}{ Alcohol consumption } \\
\hline No or former & 196 & 64.3 \\
\hline Yes & 109 & 35.7 \\
\hline \multicolumn{3}{|l|}{ Level of physical activity } \\
\hline Active & 187 & 61.3 \\
\hline Insufficiently active & 118 & 38.7 \\
\hline
\end{tabular}

*Socioeconomic classification - Brazilian Association of Research Companies (ABEP) ${ }^{10}$

The high proportion of SH women observed in the present study corroborates the literature ${ }^{20}$, and may be a reflection of the larger number of females registered in the HiperDia program $^{3}$, and may be explained by the greater concern of women with health ${ }^{21}$, longevity ${ }^{18}$, and the higher prevalence of hypertension after the age of $60^{1}$. 
Table 2. Anthropometric, clinical and laboratory characteristics of hypertensive patients followed up by the HiperDia program, São Luís, state of Maranhão, Brazil, 2010-2012

\begin{tabular}{|c|c|c|}
\hline & $\mathbf{n}$ & $\%$ \\
\hline \multicolumn{3}{|c|}{ Controlled blood pressure } \\
\hline Yes & 119 & 39.0 \\
\hline No & 186 & 61.0 \\
\hline \multicolumn{3}{|l|}{ BMI $\left(\mathbf{k g} / \mathbf{m}^{2}\right)$} \\
\hline Not overweight & 125 & 41.0 \\
\hline Overweight & 180 & 59.0 \\
\hline \multicolumn{3}{|l|}{ WC } \\
\hline Normal & 130 & 43.5 \\
\hline Altered & 169 & 56.5 \\
\hline \multicolumn{3}{|l|}{ WHR } \\
\hline Normal & 71 & 23.8 \\
\hline Altered & 228 & 76.2 \\
\hline \multicolumn{3}{|l|}{ Triglycerides (mg/dL) } \\
\hline$<150$ & 181 & 59.3 \\
\hline$\geq 150$ & 124 & 40.7 \\
\hline \multicolumn{3}{|c|}{ Total cholesterol (mg/dL) } \\
\hline$<200$ & 138 & 45.5 \\
\hline$\geq 200$ & 165 & 54.5 \\
\hline \multicolumn{3}{|c|}{ HDL cholesterol (mg/dL) } \\
\hline$\geq 40 \widehat{\partial}$ and $\geq 50$ o & 195 & 66.7 \\
\hline$<40 \AA$ and $<50$ o & 102 & 34.3 \\
\hline \multicolumn{3}{|c|}{ LDL cholesterol (mg/dL) } \\
\hline$<100$ & 71 & 23.6 \\
\hline$\geq 100$ & 230 & 76.4 \\
\hline \multicolumn{3}{|c|}{ Fasting plasma glucose (mg/dl) } \\
\hline$<100$ & 150 & 49.3 \\
\hline$\geq 100$ or Diabetic & 154 & 50.7 \\
\hline
\end{tabular}

The greater percentage of non-white individuals among hypertensive patients is also in agreement with the results of Hallal et al. ${ }^{22}$, who found associations between non-white individuals and $\mathrm{SH}$ that could represent a genetic predisposition to $\mathrm{SH}$. Another aspect that should be highlighted is the high prevalence of black and mulatto individuals in the state of Maranhão compared with those in other Brazilian states ${ }^{23}$.

The study sample was composed predominantly of individuals belonging to the lower economic classes and with a lower education level, which are common characteristics among 
Table 3. Unadjusted analysis of the association of socioeconomic, lifestyle, anthropometric and clinical laboratory characteristics with the level of physical activity in hypertensive patients followed up by the HiperDia program, São Luis, state of Maranhão, Brazil, 2010-2012

\begin{tabular}{|c|c|c|c|c|}
\hline Variables & $\begin{array}{l}\text { Active } \\
\text { n (\%) }\end{array}$ & $\begin{array}{l}\text { Insufficiently } \\
\text { active n (\%) }\end{array}$ & PR $(95 \% \mathrm{Cl})$ & $p$-value \\
\hline Sex & & & & 0.47 \\
\hline Male & $44(23.5)$ & $32(27.1)$ & $0.89(0.65 ; 1.22)$ & \\
\hline Female & $143(76.5)$ & $86(72.9)$ & 1.00 & \\
\hline Age group & & & & 0.50 \\
\hline 20-39 years & $12(6.4)$ & $5(4.2)$ & 1.00 & \\
\hline $40-59$ years & $76(40.6)$ & $43(36.5)$ & $1.22(0.57 ; 2.67)$ & \\
\hline$\geq 60$ years & $99(53.0)$ & $70(59.3)$ & $1.41(0.66 ; 3.01)$ & \\
\hline Socioeconomic status & & & & 0.41 \\
\hline Classes $A$ and $B$ & $29(15.5)$ & $13(11.0)$ & 1.00 & \\
\hline Classes $\mathrm{C} 1$ and $\mathrm{C} 2$ & $98(52.4)$ & $60(50.9)$ & $1.22(0.75 ; 2.01)$ & \\
\hline Classes $\mathrm{D}$ and $\mathrm{E}$ & $60(32.1)$ & $45(38.1)$ & $1.38(0.84 ; 2.29)$ & \\
\hline Marital status & & & & 0.26 \\
\hline With a partner & $118(63.1)$ & $82(69.5)$ & 1.00 & \\
\hline Without a partner & 69 (36.9) & $36(30.5)$ & $0.84(0.61 ; 1.14)$ & \\
\hline Skin color & & & & 0.83 \\
\hline White & $27(14.4)$ & $16(13.6)$ & 1.00 & \\
\hline Non-white & $160(85.6)$ & $102(86.4)$ & $1.04(0.68 ; 1.59)$ & \\
\hline Schooling in years & & & & 0.03 \\
\hline$\geq 8$ & $52(27.8)$ & $19(16.1)$ & 1.00 & \\
\hline$<8$ & $135(72.2)$ & 99 (83.9) & $1.58(1.04 ; 2.39)$ & \\
\hline Smoking habit & & & & 0.30 \\
\hline No or former & $134(71.7)$ & $78(66.1)$ & 1.00 & \\
\hline Yes & $53(28.3)$ & $40(33.9)$ & $1.17(0.87 ; 1.57)$ & \\
\hline Alcohol consumption & & & & 0.84 \\
\hline No or former & $121(64.7)$ & $75(63.6)$ & 1.00 & \\
\hline Yes & $66(35.3)$ & $43(36.4)$ & $1.03(0.77 ; 1.38)$ & \\
\hline
\end{tabular}

$\mathrm{PR}=$ prevalence ratio; $\mathrm{Cl}$ = confidence interval

those registered in the HiperDia program ${ }^{24}$. The literature reports that lower socioeconomic levels are associated with higher prevalence of $\mathrm{SH}$ and risk factors for hypertension ${ }^{20}$.

The prevalence of insufficiently active hypertensive individuals observed in the present study corroborates the findings of other studies that used the IPAQ. Campos et al. ${ }^{4}$ observed prevalence of insufficient physical activity of $36.9 \%$ among hypertensive individuals in the population of Montes Claros, state of Minas Gerais, Brazil, while Silva, Ricarte and Farah ${ }^{24}$ found 
Table 4. Unadjusted analysis of the association of anthropometric and clinical laboratory characteristics with the level of physical activity in hypertensive patients followed up by the HiperDia program, São Luis, state of Maranhão, Brazil, 2010-2012

\begin{tabular}{|c|c|c|c|c|}
\hline Variables & Active $\mathrm{n}(\%)$ & $\begin{array}{c}\text { Insufficiently } \\
\text { active } \\
\text { n (\%) }\end{array}$ & PR $(95 \% \mathrm{Cl})$ & $p$-value \\
\hline Controlled blood pressure & & & & 0.80 \\
\hline Yes & $74(39.6)$ & $45(38.1)$ & 1.00 & \\
\hline No & $113(60.4)$ & $73(61.9)$ & $1.03(0.78 ; 1.39)$ & \\
\hline BMI $\left(\mathbf{k g} / \mathbf{m}^{2}\right)$ & & & & 0.43 \\
\hline Not overweight & $80(42.8)$ & $45(38.1)$ & 1.00 & \\
\hline Overweight & $107(57.2)$ & $73(61.9)$ & $1.13(0.84 ; 1.51)$ & \\
\hline WC & & & & 0.21 \\
\hline Normal & $84(46.4)$ & $46(39.0)$ & 1.00 & \\
\hline Altered & $97(53.6)$ & $72(61.0)$ & $1.20(0.90 ; 1.61)$ & \\
\hline WHR & & & & 0.41 \\
\hline Normal & $46(25.4)$ & $25(21.2)$ & 1.00 & \\
\hline Altered & $135(74.6)$ & $93(78.8)$ & $1.16(0.81 ; 1.65)$ & \\
\hline Triglycerides (mg/dL) & & & & 0.82 \\
\hline$<150$ & $110(58.8)$ & $71(60.2)$ & 1.00 & \\
\hline$\geq 150$ & $77(41.2)$ & $47(39.8)$ & $0.97(0.72 ; 1.29)$ & \\
\hline Total cholesterol (mg/dL) & & & & 0.09 \\
\hline$<200$ & $78(41.7)$ & $60(51.7)$ & 1.00 & \\
\hline$\geq 200$ & $109(58.3)$ & $56(48.3)$ & $0.78(0.58 ; 1.04)$ & \\
\hline HDL cholesterol (mg/dL) & & & & 0.19 \\
\hline$\geq 40 今$ and $\geq 50$ ๆ & $88(48.1)$ & $46(40.4)$ & 1.00 & \\
\hline$<40 \overbrace{}^{\lambda}$ and $<50$ o & $95(51.9)$ & $68(59.6)$ & $1.21(0.90 ; 1.64)$ & \\
\hline LDL cholesterol (mg/dL) & & & & 0.02 \\
\hline$\leq 100$ & $36(19.4)$ & $35(30.4)$ & 1.00 & \\
\hline$>100$ & $150(80.6)$ & $80(69.6)$ & $0.71(0.53 ; 0.95)$ & \\
\hline Fasting plasma glucose (mg/dL) & & & & 0.59 \\
\hline$<100$ & $90(48.1)$ & $60(51.3)$ & 1.00 & \\
\hline$\geq 100$ or Diabetics & 97 (51.9) & $57(48.7)$ & $0.93(0.69 ; 1.23)$ & \\
\hline
\end{tabular}

$\mathrm{PR}=$ prevalence ratio $\mathrm{Cl}=$ confidence interval; $\mathrm{BMI}=$ body mass index $\mathrm{WC}=$ waist circumference; $\mathrm{WHR}=$ waist-to-hip ratio; $\mathrm{HDL}=$ high-density lipoprotein; $\mathrm{LDL}=$ low-density lipoprotein

prevalence of insufficient physical activity of $29.6 \%$ in patients registered in the HiperDia program in Recife, state of Pernambuco, Brazil.

In Brazil, population-based studies conducted in the municipalities of Montes Claros and São Paulo using the IPAQ short form observed prevalence of insufficiently active individuals 
Table 5. Adjusted analysis of the association of socioeconomic, lifestyle, anthropometric and clinical laboratory characteristics with the level of physical activity in hypertensive patients followed up by the HiperDia program, São Luis, state of Maranhão, Brazil, 2010-2012

\begin{tabular}{lccc}
\multicolumn{1}{c}{ Variables } & PR & $(\mathbf{9 5} \% \mathbf{C l})$ & $\boldsymbol{p}$-value \\
\hline Schooling in years & & & \\
\hline$\geq 8$ & 1.00 & & \\
\hline$<8$ & 1.50 & 0.05 & $\mathbf{0 . 0 2}$ \\
\hline LDL cholesterol (mg/dL) & & & \\
\hline$\leq 100$ & 1.00 & & \\
\hline$>100$ & 0.72 & $0.54 ; 0.96$ & \\
\hline
\end{tabular}

$\mathrm{PR}=$ prevalence ratio; $\mathrm{Cl}=$ confidence interval; $\mathrm{LDL}=$ low-density lipoprotein

of approximately $26 \%^{4}$. Higher values were detected among adult (37.1\%) and older $(68.0 \%)$ individuals in a survey conducted with patients registered in the FHS in Recife ${ }^{3}$.

Despite some aspects, which are inherent in the individual and the environment, not evaluated in this study, it is possible that these factors act as barriers for the practice of physical activity, and that they may have influenced the results. The barriers encountered by older persons are related to external factors and the provision of health services ${ }^{25}$.

In contrast, using the extended version of the IPAQ, Martins et al..$^{26}$ observed prevalence of $80 \%$ of low and moderate physical activity in hypertensive patients from a referral outpatient care center in the state of Ceará, Brazil. This discrepancy with the literature was explained by the authors: they used the extended version of the IPAQ and maintained the three classification levels of physical activity suggested by the instrument.

High rates of physical inactivity have become a global concern', as the literature has shown their association with demographic, socioeconomic and health variables s.3,4. Among $^{2}$. Ampared inactive hypertensive patients, a more than 2 -fold increase in the risk of mortality compared with active individuals has been observed ${ }^{27}$.

The insufficient physical activity observed in the present study was associated with education level and LDL cholesterol serum levels. Hypertensive patients with fewer than 8 years of schooling were 1.6 times more likely to be insufficiently active than those with more schooling. This finding corroborates other studies that have observed a direct association between physical activity and education level ${ }^{27}$.

According to the literature, individuals with higher education levels have higher levels of physical activity during leisure time ${ }^{19}$, while those with lower education levels have less access to exercise equipment, adequate and safe public places or private places for exercising, and less knowledge about the health benefits of physical activity ${ }^{27}$. A study revealed that the variable lipid profile did not differ between men with good and poor levels of physical activity ${ }^{28}$.

In this study, hypertensive and insufficiently active patients presented a smaller tendency to high LDL cholesterol serum levels. In this aspect, the literature is inconsistent, because although this study observed similar results ${ }^{28}$, most studies have shown higher risks of finding atherogenic lipid profile in sedentary individuals ${ }^{29}$, which is attributed to complex interactions that involve hormones, enzymes, and receptors ${ }^{18}$.

This inconsistence can be attributed to the cross-sectional design of this study, which is not able to identify the cause-effect relationship. It is possible that the association observed in this study - between the insufficient practice of physical activity and high LDL cholesterol serum levels - was an attempt of hypertensive individuals to start practicing physical activities to treat dyslipidemia. Also, other factors can influence dyslipidemia, as the use of lipid-lowering medication and the stress level - these factors were not analyzed in this study. 
Possible limitations to this study include the survival bias and lack of drug therapy evaluation. However, it should be considered that all the patients were enrolled in the HiperDia program and had access to the treatments recommended by the Brazilian Ministry of Health (MS).

In contrast, the strengths of the present study include obtaining laboratory tests and the use of anthropometric and BP measures by direct measurement, and not by self-reference. We emphasize that the diagnosis of insufficient physical activity using the IPAQ can be useful in the daily routine of the Brazilian Unified Health System (SUS), since it can be easily obtained, presents a lower cost for the screening of hypertensive patients at a metabolic risk, is useful in the prevention and treatment of chronic diseases, and can be included in the clinical practice.

There was significant prevalence of insufficient physical activity and its association with low education level and altered LDL cholesterol levels in hypertensive patients.

Therefore, there is a necessity to implement actions that encourage the practice of physical activity, such as the creation of public spaces focused on the practice of exercises, as well as the valorization and hiring of physical education professionals to perform proper and direct guidelines on this practice, considering the clinical, sociodemographic and cultural characteristics of this population.

\section{REFERENCES}

1. Brasil. Ministério da Saúde. Secretaria de Vigilância em Saúde. Departamento de Análise de Situação de Saúde. Plano de ações estratégicas para o enfrentamento das doenças crônicas não transmissíveis (DCNT) no Brasil 2011-2022 / Ministério da Saúde. Secretaria de Vigilância em Saúde. Departamento de Análise de Situação de Saúde. Brasília: Ministério da Saúde; 2011.

2. Martins LCG, Guedes NG, Teixeira IX. Nível de atividade física em portadores de hipertensão arterial. Rev Lat Am Enfermagem. 2009;17(4):462-7. http://dx.doi.org/10.1590/S0104-11692009000400005. PMid:19820851.

3. Alves JGB, Siqueira FV, Figueiroa JN, Facchini LA, Silveira DS, Piccini RX, et al. Prevalência de adultos e idosos insuficientemente ativos moradores em áreas de unidades básicas de saúde com e sem Programa Saúde da Família em Pernambuco, Brasil. Cad Saude Publica. 2010;26(3):543-56. http://dx.doi.org/10.1590/ S0102-311X2010000300012. PMid:20464073.

4. Campos M, Maciel MG, Rodrigues J No. Atividade física insuficiente: fatores associados e qualidade de vida. Rev Bras Ativ Fís Saúde. 2012;17(6):562-72. http://dx.doi.org/10.12820/2317-1634.2012v17n6p562.

5. Cichocki M, Fernandes KP, Castro-Alves DC, Gomes MVM. Atividade física e modulação do risco cardiovascular. Rev Bras Med Esporte. 2017;23(1):21-5. http://dx.doi.org/10.1590/1517-869220172301159475.

6. Silveira J, Scherer F, Deitos A, Bosco SMD. Fatores associados à hipertensão arterial sistêmica e ao estado nutricional de hipertensos inscritos no programa Hiperdia. Cad Saude Colet. 2013;21(2):129-34. http:// dx.doi.org/10.1590/S1414-462X2013000200005.

7. IPAQ Group. International Physical Activity Questionnaire [Internet]. 2011 [cited 2013 Aug 6]. Available from: http://www.ipaq.ki.se.

8. Brasil. Ministério da Saúde. Secretaria de Vigilância em Saúde. Secretaria de Gestão Estratégica e Participativa. Vigitel Brasil 2010: vigilância de fatores de risco e proteção para doenças crônicas por inquérito telefônico. Brasília: Ministério da Saúde; 2012.

9. Florindo AA, Guimaraes VV, Cesar CLG, Barros MBA, Alves MCG, Goldbaum M. Epidemiology of leisure, transportation, occupational, and household physical activity: prevalence and associated factors. J Phys Act Health. 2009;6(5):625-32. http://dx.doi.org/10.1123/jpah.6.5.625. PMid:19953839.

10. Associação Brasileira de Empresas de Pesquisa [Internet]. 2009 [cited 2013 Aug 6]. Available from: www. abep.org.

11. World Health Organization. Waist circumference and waist-hip ratio. Geneva: WHO; 2008.

12. World Health Organization. Obesity - preventing and managing the global epidemic. Geneva:WHO; 1998.

13. Lipschitz DA. Screening for nutritional status in the elderly. Prim Care. 1994;21(1):55-67. http://dx.doi. org/10.1016/S0095-4543(21)00452-8. PMid:8197257.

14. Simão AF, Precoma DB, Andrade JP, Correa H Fo, Saraiva JFK, Oliveira GMM, et al, and the Sociedade Brasileira de Cardiologia. I Diretriz Brasileira de Prevenção Cardiovascular. Arq Bras Cardiol. 2013;101(6 Suppl Suppl 2):1-63. http://dx.doi.org/10.5935/abc.2013S012. PMid:24554026. 
15. Malachias M, Plavnik FL, Machado CA, Malta D, Scala LCN, Fuchs S. 7th Brazilian Guideline of Arterial Hypertension: Chapter 1 - Concept, Epidemiology and Primary Prevention. Arq Bras Cardiol. 2016;107(3 Suppl Supl.3):1-6. PMid:27819380.

16. American Diabetes Association. Diagnosis and classification of Diabetes Mellitus. Diabetes Care. 2011;34(Suppl Suppl 1):S62-9. PMid:21193628.

17. Expert Panel on Detection, Evaluation, and Treatment of High Blood Cholesterol in Adults. Executive summary of The Third Report of The National Cholesterol Education Program (NCEP) Expert Panel on Detection, Evaluation, And Treatment of High Blood Cholesterol In Adults (Adult Treatment Panel III). JAMA. 2001;285(19):2486-97. http://dx.doi.org/10.1001/jama.285.19.2486. PMid:11368702.

18. Robles NR, Macias JF. Hypertension in the elderly. Cardiovasc Hematol Agents Med Chem. 2015;12(3):13645. http://dx.doi.org/10.2174/1871525713666150310112350. PMid:25761101.

19. Ferri C, Ferri L, Desideri G. Management of hypertension in the elderly and frail elderly. High Blood Press Cardiovasc Prev. 2017;24(1):1-11. http://dx.doi.org/10.1007/s40292-017-0185-4. PMid:28181201.

20. Sociedade Brasileira de Cardiologia. Sociedade Brasileira de Hipertensão, Sociedade Brasileira de Nefrologia. 7a Diretriz Brasileira de Hipertensão Arterial. Arq Bras Cardiol. 2016;107(3 Suppl 3)

21. Picon RV, Dias-da-Costa JS, Fuchs FD, Olinto MTA, Choudhry NK, Fuchs SC. Hypertension management in Brazil: usual practice in Primary Care - a meta-analysis. Int J Hypertens. 2017;2017:1274168. http://dx.doi. org/10.1155/2017/1274168. PMid:28751987.

22. Hallal PC, Andersen LB, Bull FC, Guthold R, Haskell W, Ekelund U, et al. Global physical activity levels: surveillance progress, pitfalls, and prospects. Lancet. 2012;380(9838):247-57. http://dx.doi.org/10.1016/ S0140-6736(12)60646-1. PMid:22818937.

23. Brasil. Ministério da Saúde, Secretaria de Vigilância em Saúde, Secretaria de Gestão Estratégica e Participativa. Vigitel Brasil 2017: vigilância de fatores de risco e proteção para doenças crônicas por inquérito telefônico. Brasília: Ministério da Saúde; 2017.

24. Souza CS, Stein AT, Bastos GAN, Pellanda LC. Blood pressure control in hypertensive patients in the "Hiperdia Program": a territory-based study. Arq Bras Cardiol. 2014;102(6):571-8. PMid:25004419.

25. Quiroz-Mora CA, Serrato-Ramírez DM, Bergonzoli-Peláez G. Factores asociados con la adherencia a la actividad física en pacientes con enfermedades crónicas no transmisible. Rev Salud Publica (Bogota). 2018;20(4):460-4. http://dx.doi.org/10.15446/rsap.v20n4.62959. PMid:30843981.

26. Rossi A, Dikareva A, Bacon SL, Daskalopoulou SS. The impact of physical activity on mortality in patients with high blood pressure: a systematic review. J Hypertens. 2012;30(7):1277-88. http://dx.doi.org/10.1097/ HJH.0b013e3283544669. PMid:22573122.

27. Turi BC, Bonfim MR, Codogno JS, Fernandes RA, Araújo LGM, Amaral SL, et al. Exercise, blood pressure and mortality: findings of eight years of follow-up. Rev Bras Med Esporte. 2017;23(2):133-6. http://dx.doi. org/10.1590/1517-869220172302158989.

28. Nieburg I, Kahan T. Cardiovascular risk factors are not treated to target in hypertensive patients in primary care. Blood Press. 2010;19(3):176-81. http://dx.doi.org/10.3109/08037051.2010.483053. PMid:20429693.

29. Edwards MK, Blaha MJ, Loprinzi PD. Influence of sedentary behavior, physical activity, and cardiorespiratory fitness on the atherogenic index of plasma. J Clin Lipidol. 2017;11(1):119-25. http://dx.doi.org/10.1016/j. jacl.2016.10.014. PMid:28391877. 